\title{
Essential oil composition in natural population of Lippia origanoides (Verbenaceae) during dry and rainy seasons
}

\author{
Luciana M. Souza, Francine S. A. Fonseca, Júlio C. R. L. Silva, Amanda M. Silva, \\ Julian R. Silva \& Ernane R. Martins \\ Laboratório de Plantas Medicinais e Aromáticas do Instituto de Ciências Agrárias, Universidade Federal de Minas \\ Gerais - Avenida Universitária, 1.000, Bairro Universitário, Montes Claros - MG, CEP: 39.404-547. Brasil; \\ lumesouza@yahoo.com.br, francinefonseca@yahoo.com.br, juliocesarls2009@hotmail.com, \\ amandamaiaesilva@hotmail.com,julian.ufmg@gmail.com, ernane.ufmg@gmail.com
}

Received 20-XI-2017. Corrected 17-X-2018. Accepted 28-I-2019.

\begin{abstract}
Lippia origanoides Kunth. is a medicinal shrub native to some countries in South America, Central America and the Caribbean. This study aims to investigate the chemical composition of the essential oil and the genetic diversity of a natural population of Lippia origanoides in two seasons. Leaf samples were collected from 30 individuals in the dry and rainy seasons. The essential oil was extracted into a Clevenger apparatus and analyzed by gas chromatography coupled to mass spectrometry (GC-MS). The relative quantification of thymol and carvacrol was performed by gas chromatography coupled to a flame ionization detector (GC-FID). Multivariate analysis was used to evaluate the genetic divergence between plants. Carvacrol was the major compound found in most plants for both seasons. In the rainy season, plant 15 presented thymol as the major compound, and plants 16, 27, 28 and 29 presented camphor as the major compound. In the dry season, thymol remained the main compound of plant 15 and camphor remained the main compound of plants 16, 28 and 29; however, plant 27 presented carvacrol as the main compound in this season. After carvacrol, the compounds with the highest content were $\gamma$-terpinene, $p$-cymene and methyl-ether-thymol. Of the 30 plants studied, only five differed in their chemical composition, showing some degree of stability in relation to the dry and rainy seasons. There was no variation in the main compounds between the two seasons, but there was chemical diversity among the main compounds. Tocher grouping revealed five distinct groups, with group 1 including most of the plants in both dry and rainy seasons, indicating that the time of year evaluated did not significantly interfere with the essential oil composition of most plants.
\end{abstract}

Key words: hydrodistillation; diversity; chemical composition; harvest time; thymol; carvacrol.

Souza, L. M., Fonseca, F. S. A., Silva, J. C. R. L., Silva, A. M., Silva, J. R., \& Martins, E. R. (2019).Essential oil composition in natural population of Lippia origanoides (Verbenaceae) during dry and rainy seasons. Revista de Biología Tropical, 67(1), 278-285.

Lippia origanoides Kunth., popularly known as "alecrim-pimenta", is a shrub native to some countries in South America, Central America and the Caribbean (Henao, Muñoz, Rios, Padilla, \& Giraldo, 2009). Infusions of its leaves, aerial parts and flowers are traditionally used as a topical lotion for respiratory diseases, in the treatment of gastrointestinal disorders and as a carminative, as well as an anti-septic for the mouth, throat and wounds (Pascual, Slowing, Carretero, Sánchez Mata, \& Villar, 2001). Studies have shown its antimicrobial, antifungal, antiviral (Dos Santos et al., 2004; Meneses et al., 2009; Tangarife-Castaño et al. 2012) and action antiparasitics (Escobar et al., 2010; Borges et al., 2012).

Its biological activities vary depending on the chemical constitution of its essential oil 
and there may be genetic divergence within the same population (Vega-Vela, Delgado-Avila, \& Chacon Sanchez, 2013). In addition, essential oil yield and composition may be influenced by harvest time as well as characteristics associated to temperature, rainfall and humidity indices (Teles, 2010).

Variation in accordance with the main essential oil constituents has led to its classification by chemotype (Dos Santos et al., 2004; Oliveira et al., 2007; Castañeda, Muñoz, Martínez, \& Stanshenko, 2007; Zapata, Duran, Stashenko, Correa-Royero, \& Betancur-Galvis, 2009; Stashenko et al., 2010). Therefore, the chemical identification of its compounds provides basic information for selecting plants of interest and for proper application (Stashenko et al., 2010).

Several factors may be related to the chemical production and constitution of $L$. origanoides essential oil and these factors are of fundamental importance in plant improvement programs aiming toward phytotherapeutic application, since the action of essential oils is related to their chemical constitution (Martins \& Pólo, 2006). This study aimed to analyze the chemical composition of the essential oil and genetic diversity of a natural population of $L$. origanoides in two seasons of the year.

\section{MATERIALS AND METHODS}

Plant material: This study was carried out in a natural reserve area of the Institute of Agrarian Sciences of the Federal University of Minas Gerais, located in the city of Montes

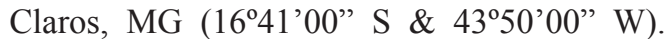
Exsiccates of the species were deposited in the Agricultural Research Company of Minas Gerais (EPAMIG) herbarium under No 56524 and No 56 526. The plants selected for the study were at least $50 \mathrm{~m}$ apart and were marked by plaques with the corresponding number. Leaves from the same plants (30 individuals) were collected in two seasons, once in the dry season (May 2013) and once in the rainy season (February 2014). In the rainy season, the plants were full of leaves and flowers, whereas in the dry season the plants presented few leaves and were not flowery. After collection, the leaves were taken to the Laboratory of Medicinal Plants (ICA-UFMG) and stored in a freezer $\left(-4^{\circ} \mathrm{C}\right)$.

Study area: The collection area is 35.9 hectares and has an average altitude of 632 m (software GPS Trackmaker). The region's climate is Aw, according to the Köppen classification, with a well-defined dry season and rains concentrated in the months between November and January (Köppen, 1931).

The climatic data of the study period were obtained from the website of the Brazilian National Institute of Meteorology (INMET, 2015). In the two seasons used in this study, there was no variation in total insolation, average temperature and relative humidity. The precipitation was $25.1 \mathrm{~mm}$ in the rainy season and in the dry season there was no precipitation (INMET, 2015) (Table 1).

TABLE 1

Climatic data in the period of collection of the natural population of Lippia origanoides at the Institute of Agrarian Sciences, Montes Claros, MG

\begin{tabular}{lcc} 
& Dry & Rainy \\
Total insolation $(\mathrm{h})$ & 272.9 & 271.8 \\
Relative humidity $(\%)$ & 62.3 & 62.3 \\
Average temperature $\left({ }^{\circ} \mathrm{C}\right)$ & 22.6 & 22.6 \\
Total rainfall $(\mathrm{mm})$ & 0 & 25.0 \\
\hline
\end{tabular}

Data was collected in May of 2013 (dry season) and in February of 2014 (rainy season).

Source: http://www.inmet.gov.br/portal/

Extraction of essential oil: The essential oil was extracted from the fresh leaves $(40 \mathrm{~g})$ by hydrodistillation, using a Clevenger apparatus $(2 \mathrm{~h})$. After extraction, the volume of the oil was determined weighing the empty bottle in the analytical balance (Mars AY220) and then weighing the bottle with oil. For dry matter determination, the vegetal material resulting from the oil extraction was subjected to drying in a forced air circulation oven at $60{ }^{\circ} \mathrm{C}$ until constant weight. After extraction, the essential 
oil samples were weighed and dried with anhydrous sodium sulfate and subsequently stored $\left(-4{ }^{\circ} \mathrm{C}\right)$ in amber flasks. The yield (\%) of essential oil was calculated by dividing the volume of the oil by the weight of the dry matter of the sample.

Identification of essential oil components and quantification of timol and carvacrol: The samples were submitted to chromatographic analysis 7890A (Agilent Technologies) coupled to a mass spectrometer (MS 5975C) with a fused silica capillary column DB5-MS (30 $\mathrm{m} \times 0.25 \mathrm{~mm} \times 0.25 \mu \mathrm{m})$ using helium ( $99.99 \%$ of purity) as drag gas with a flow of $1 \mathrm{~mL} \mathrm{~min}{ }^{-1}$. The injector was kept at $220{ }^{\circ} \mathrm{C}$, with a flow split ratio of $1: 5$, following the temperature of $60-240{ }^{\circ} \mathrm{C}\left(3{ }^{\circ} \mathrm{C} \mathrm{min}-1\right)$ kept for 10 $\min$. The interface temperature was maintained at $240{ }^{\circ} \mathrm{C}$. The system was operated in full scan with electron impact of $70 \mathrm{eV}$, in the range of $45-550(\mathrm{~m} / \mathrm{z})$. The retention index of all compounds was calculated from the retention time of a mixture of $n$-alkanes $\left(\mathrm{C}_{7}-\mathrm{C}_{40}\right.$, Sigma USA) 20 ppm, split 1:100.

The generated data were analyzed using MSDE ChemStation software. The relative abundance (\%) of the total ions was calculated from the peak area of the chromatogram (GCMS) and organized according to the order of elution. Identification of the compounds was performed by comparing the mass spectrum with that of the library NIST 2.0 (2009), by the relative retention index (RI), calculated according to Van den Dool \& Kratz (1963), and compared with information in the literature (Adams, 2012).

The quantification of thymol and carvacrol (Sigma Aldrich) was performed in a gas chromatograph coupled to a flame ionization detector (GC-FID), operated under the same GC-MS conditions, except for the chromatographic column, which was HP-5 (30 m x $0.25 \mathrm{~mm} \times 0.25$ $\mu \mathrm{m})$ with nitrogen gas entrainment (99.99\% of purity). The injector was maintained at 220 ${ }^{\circ} \mathrm{C}$, with a flow split ratio of $1: 5$, following the setting temperature of $60-240{ }^{\circ} \mathrm{C}\left(3{ }^{\circ} \mathrm{C} \mathrm{min}{ }^{-1}\right)$ and the detector temperature of $240{ }^{\circ} \mathrm{C}$.
Statistical analyses: An analysis of variance (ANOVA) was used to compare mean yield of essential oil between the two seasons and also to compare the mean content of the compounds (season dry and rainy) in Sisvar software, version 5.6 (Ferreira, 2011). Multivariate analysis was performed with the statistical program GENES (Cruz, 2006) to evaluate the genetic divergence between plants in relation to the major chemical compounds in the dry and rainy seasons. The major chemical compounds of the 30 plants were used to make the analysis, verifying the differences and similarities between the plants according to the presence or absence of the chemical compound in the dry and rainy seasons. As a measure of dissimilarity, we used the mean Euclidean distance, which represents the diversity that exists in the set of plants studied. After calculating the mean Euclidean distance, cluster analysis was performed using the Tocher optimization method, which is a simultaneous grouping method that classifies genotypes according to their genetic distances.

\section{RESULTS}

The mean essential oil yield of L. origanoides leaves collected during the dry season was of $3.7 \% \pm 0.8 \%$. In the rainy season a mean was of $4.9 \% \pm 1.3 \%$. The analysis of variance showed that the collection season affected the mean essential oil yield, and the rainy season had a higher essential oil yield.

There were 67 compounds detected in the analysis of the chemical composition. The essential oil showed mainly monoterpenes (44 $\%$ ) and sesquiterpenes (20\%). Carvacrol was the most abundant compound in most of the plants studied, both in the dry and the rainy season. The analysis of variance showed that the averages of the content of the mains compounds in the two seasons did not differ from each other (Table 2).

In the dry season, plant 11 had the highest carvacrol content $(62.5 \%)$. In plants 16,27 and 28 thymol and carvacrol were not detected, 
TABLE 2

Average relative abundance of the chemical main compounds detected in the essential oil of Lippia origanoides

\begin{tabular}{lcccc}
\multicolumn{1}{c}{ Compounds } & $\mathrm{RI}_{\mathrm{Cal}}$ & $\mathrm{RI}_{\text {Lit }}$ & $\mathrm{R}$ & $\mathrm{D}$ \\
camphene & 948 & 951 & $9.9 \pm 6.0 \mathrm{a}$ & $10.1 \pm 5.9 \mathrm{a}$ \\
$p$-cymene & 1023 & 1025 & $14.0 \pm 4.8 \mathrm{a}$ & $15.8 \pm 8.6 \mathrm{a}$ \\
$y$ - terpinene & 1055 & 1062 & $4.6 \pm 2.8 \mathrm{a}$ & $5.6 \pm 3.7 \mathrm{a}$ \\
camphor & 1147 & 1143 & $3.5 \pm 10.5 \mathrm{a}$ & $3.4 \pm 10.5 \mathrm{a}$ \\
methyl-ether-thymol & 1227 & 1235 & $5.2 \pm 3.1 \mathrm{a}$ & $5.6 \pm 3.4 \mathrm{a}$ \\
thymol & 1289 & 1292 & $6.9 \pm 13.0 \mathrm{a}$ & $6.7 \pm 11.9 \mathrm{a}$ \\
carvacrol & 1300 & 1298 & $49.3 \pm 22.5 \mathrm{a}$ & $43.1 \pm 22.2 \mathrm{a}$ \\
\hline
\end{tabular}

RIcal - Retention Index calculed, RILit - Retention Index Literature. R: Rainy season. D: Dry season. Note: The compounds are shown according to retention time. * Only those compounds that were found as main compounds in the present study are shown. The means are followed by the standard deviation. Means followed by the same letter in the column do not differ from one another by analysis of variance.

and these plants presented camphor as the main compound. In plant 15 , carvacrol was not detected and thymol was the main compound $(43.9 \%)$. In plants 14 and 17, thymol was not detected.

In the rainy season, plant 26 had the highest carvacrol content $(67.3 \%)$. Plant 15 was the only one to present thymol as the main compound (47.5\%) and it presented a low content of carvacrol (3.2\%). In plant 29 , the main compound was camphor and the compounds carvacrol and thymol were not detected in that season. In plant 28 , camphor was the main compound, while carvacrol was detected in low content $(7.47 \%)$ and thymol was not detected.

In addition to carvacrol and thymol, there were other main compounds detected in the essential oil of $L$. origanoides. Following carvacrol, the compounds that presented the highest content in most plants were $\gamma$-terpinene, $p$-cymene and methyl-ether-thymol. In general, the content of these compounds did not vary between dry and rainy seasons in most plants.

In the dry season, plant 1 presented $p$-cymene as the main compound (46.7\%). Camphor was the main compound in plants 16 (36\%), $27(38.5 \%)$ and $28(23.1 \%)$ and in these plants $\gamma$-terpinene, $p$-cymene and methylether-thymol were not detected. In plant 29, the main compound was carvacrol (55.6\%) and $p$-cymene was not detected, whereas a low content of $\gamma$-terpinene $(4.9 \%)$ and methylether-thymol $(6.6 \%)$ was detected.

In the rainy season, plant 1 presented carvacrol as the main compound $(71.9 \%)$ and a lower content of $p$-cymene (18.4\%), when compared to the dry season. Camphor was the main compound in plants 16 (38.6\%), 28 (37.8\%) and 29 (25.5\%). In plants 16 and 28, a low content of $\gamma$-terpinene, $p$-cymene and methyl-ether-thymol was detected while these compounds were not detected in plant 29. In plant 16 , there was an increase in the content of $p$-cymene $(1.7 \%)$ and methyl-ether-thymol $(1.3 \%)$, when compared to the dry season.

Grouping Analysis: Table 3 shows the plants grouped according to the Tocher optimization method for the dry and rainy seasons. Tocher grouping revealed five distinct groups, with group 1 including most of the plants in the dry or rainy season, indicating that the time of year did not significantly interfere with the essential oil composition of most plants. Only plants $16,29,1$ and 15 were allocated in distinct groups, showing that important differences occurred between the dry and rainy season for these plants.

This result is in agreement with the chemical analyses of the essential oil, because the plants that were allocated in distinct groups presented different chemical characteristics 
TABLE 3

Grouping of plants from natural population of Lippia origanoides according to the Tocher optimization method

\begin{tabular}{cl} 
Group & \multicolumn{1}{c}{ Plants } \\
1 & 2D, 27D, 12D, 5D, 4D, 9D, 10D, 5R, 21D, 30D, 7D, 1R, 20D, 30R, 20R, 17D, 3D, 25D, 11D, 19D, 17R, 25R, \\
& 3R, 24D, 23D, 2R, 8D, 14D, 12R, 27R, 4R, 10R, 7R, 9R, 13D, 14R, 22R, 8R, 26R, 21R, 11R, 22D, 26D, \\
& 19R, 13R, 24R, 28D, 23R, 18R, 29D, 15R, 16D, 18D, 6R, 28R, 6D \\
2 & 16R \\
3 & 29R \\
4 & 1D \\
5 & 15D \\
\hline
\end{tabular}

The number corresponds to the plant.

D: Dry season, R: Rainy season.

Source: GENES Program.

when compared to the other plants of the population. Plant 16, presented camphor as the main compound and a low content of thymol in the rainy season. Plant 29 presented camphor as the main compound, while thymol and carvacrol were not detected in the rainy season. In plant $1, p$-cymene was the main compound in the dry season, while carvacrol was the main compound in the rainy season. In plant 15 , thymol was the main compound both in the dry and the rainy season.

\section{DISCUSSION}

This research showed that harvesting in the dry and rainy seasons affected the mean yield of essential oil of $L$. origanoides. Ramirez, Isaza, Veloza, Stashenko, \& Marin (2009), studying plants collected in different regions and times in Colombia, found that the essential oil of $L$. origanoides varied from 0.4 to $4.4 \%$. Ribeiro, Andrade, Salimena, \& Maia (2014), investigating a wild population of plants collected in dry and rainy seasons, found a variation between 1.7 and $4.6 \%$, with greater essential oil content in the dry season. Several factors should be considered in relation to essential oil yield, including temperature and rainfall index (Gobbo-Neto \& Lopes, 2007).

In this study, carvacrol was the most abundant compound, in most of the plants analyzed, both in the dry and the rainy season. Thymol was the main compound only in plant 15 , for both seasons. Ramirez et al. (2009) found that essential oil of $L$. origanoides presenting higher percentages of carvacrol presented greater zones of inhibition against Pseudomonas aeruginosa than did oils with greater percentages of thymol, when these compounds were evaluated independently.

Besides thymol and carvacrol, $\gamma$-terpinene, $p$-cymene and methyl-ether-thymol were also found as main compounds. Sarrazin et al. (2015) evaluated the influence of seasonal variation and found that carvacrol was the most abundant compound both in the rainy and dry seasons, followed by thymol, $p$-cymene and p-methoxythymol.

Variations in the quantities of the main components of the essential oils of different samples of $L$. origanoides, such as carvacrol, thymol, trans- $\beta$-cariophyllene, $\rho$-cimene, $\beta$-mircene, $\alpha$-humulene and $g$-terpinene, were classified into chemotypes according to their chemical composition (Oliveira et al., 2006). According to Vicuña, Stashenko, \& Fuentes (2010), there are at least three different chemotypes of $L$. origanoides, one being characterized by presenting carvacrol as the main compound, another characterized by presenting thymol as the main compound and a third more rare chemotype characterized by the absence or very low content of these compounds.

In an investigation of the chemical composition of the essential oil of cultivated $L$. origanoides plants, Teixeira et al. (2014), found 
carvacrol as the main compound (41.5\%). Dos Santos et al. (2004), analyzing three collections of $L$. origanoides also observed carvacrol as the main compound (33.5 to $42.9 \%$ ). However, in a research comparing the chemical composition of the essential oils of $L$. origanoides, from the leaves collected in the dry and rainy seasons, thymol was found as the main compound (45 to $62 \%$ ) (Rojas et al., 2006). In a study of the chemical composition of the essential oil of $L$. origanoides in a natural population of plants thymol, was also the main compound (34 a 60 \%) (Vicuña et al., 2010).

In an investigation of the chemical composition of $L$. origanoides essential oil, $p$-cymene $(11.9-15.8 \%), \gamma$-terpinene $(8.0-10.5 \%)$ and thymol (5.1 - $8.4 \%)$ were the main constituents (Dos Santos et al., 2004). In a research carried out by Oliveira et al. (2007), the main compound was carvacrol (38.6\%), followed by thymol $(18.5 \%)$, p-cymene $(10.3 \%)$ and $\gamma$-terpinene $(4.1 \%)$.

In this study, plants 15, 16, 27, 28 and 29 differed from most of the other plants in their chemical composition, mainly in relation to the presence of thymol and carvacrol, compounds characteristic of $L$. origanoides. These compounds were absent in plants 16, 27 and 28, which presented main compounds such as camphor and camphene, reported in the literature to present moderate antimicrobial action (Tirillini, Velasquez, \& Pellegrino, 1996).

The natural population did not show great variation in chemical composition of the essential oil in relation to the dry and rainy seasons, since only plants $15,16,27,28$ and 29 differed chemically from the others, indicating some stability in the chemical composition of the population studied.

The biological activities and potential applications of essential oils depend on their composition, which may vary within a single species (Vega-Vela et al., 2013). Knowledge of the genetic structure of populations of a species is important for managing genetic resources for conservation or domestication (Falk, Knapp, \& Guerrant, 2001).
The chemical composition of essential oils of Lippia spp is determined by genetic and environmental factors, which may lead to significant changes in the production of the secondary metabolites of these plants. The action of abiotic factors on the content and composition of essential oils may be influenced by seasonality (Silva, Oliveira, Costa, Bizzo, \& Oliveira, 2006; Nogueira, Diaz, \& Sakumo, 2007; Morais, 2009), availability of water, luminosity, temperature, stage of development and nutritional status (Gobbo-Neto \& Lopes, 2007).

The variability of chemical constituents of the essential oil determines the different pharmacological actions of $L$. origanoides. The lack of knowledge related to its chemical components may lead to risks and uncertainties related to its consumption. Therefore, studying its chemical composition and genetic structure is important for proper utilization. The essential oil of $L$. origanoides has the potential for development of therapeutic products and the stability in the production of chemical compounds during the year is an important factor for the pharmaceutical industry to be interested in the use of its essential oil for drug development, which may lead to creation of a production chain based on sustainable management or production.

There was variation in the essential oil yield of $L$. origanoides and the rainy season had a higher essential oil yield. There was no variation in the main compounds between the two seasons, but there was chemical diversity among the main compounds. Carvacrol was the main compound in most plants in the dry and rainy seasons. Only five plants differed chemically from the others, indicating a certain degree of stability in the chemical composition in relation to the dry and rainy seasons. Few plants showed variation in chemical composition and the time of year did not influence the production of compounds in the plants of this natural population.

Ethical statement: authors declare that they all agree with this publication and made 
significant contributions; that there is no conflict of interest of any kind; and that we followed all pertinent ethical and legal procedures and requirements. A signed document has been filed in the journal archives.

\section{ACKNOWLEDGMENTS}

\section{Thank you to CNPq, FAPEMIG and sup- port from SESU-PET.}

\section{RESUMEN}

\section{Composición de los aceites esenciales en pobla-} ciones naturales de Lippia origanoides (Verbenaceae) durante las estaciones seca y lluviosa. Lippia origanoides Kunth. es un arbusto medicinal nativo de algunos países de Centro y Sur América y el Caribe. El objetivo de este estudio fue investigar la composición química de los aceites esenciales y la diversidad genética de una población natural de $L$. origanoides en dos estaciones. El aceite esencial se extrajo en un equipo de Clevenger y se analizó por cromatografía de gases acoplado a espectrometría de masas (CG-EM). La cuantificación relativa de timol y carvacrol se realizó por cromatografía de gases acoplado a un detector de ionización de llamas (CG-DIL). Se utilizó un análisis multivariado para evaluar la divergencia genética entre plantas. El carvacrol fue el compuesto principal encontrado en la mayoría de las plantas para ambas estaciones. En la estación lluviosa, la planta 15 presentó timol como el compuesto principal y las plantas $16,27,28$ y 29 presentaron alcanfor como el compuesto principal. En la estación seca, el timol se mantuvo como el principal compuesto en la planta 15 , de igual manera el alcanfor se mantuvo como el principal en las plantas 16, 28 y 29. Sin embargo, la planta 27 presentó carvacrol como el principal compuesto en esta estación. Después del carvacrol, los compuestos con el mayor contenido fueron $\gamma$-terpineno, p-cimeno and metil-eter-timol. De las 30 plantas estudiadas, solo cinco difirieron en su composición química, mostrando algún grado de estabilidad en relación a la estación seca y lluviosa. No hubo variación en los compuestos principales entre las dos estaciones, pero hubo diversidad química entre los compuestos principales. El agrupamiento de Tocher mostró cinco grupos distintos, con el grupo 1 incluyendo la mayoría de las plantas en ambas estaciones, lo cual indica que el periodo del año evaluado no interfiere significativamente con la composición de aceites esenciales en la mayoría de plantas.

Palabras clave: hidrodestilación; diversidad; composición química; tiempo de cosecha; timol; carvacrol.

\section{REFERENCES}

Adams, R. P. (2012). Identification of essential oil components by gas chromatography/mass spectrometry. Caro Stream, IL, USA: Allured Publishing Corporation.

Borges, A. R., Aires, J. R., Higino, T. M., Medeiros, M. D., Citó, A. M., Lopes, J. A., \& Figueiredo, R. C. (2012). Trypanocidal and cytotoxic activities of essential oils from medicinal plants of Northeast of Brazil. Experimental Parasitology, 32(2), 123-128.

Castañeda, M. L., Muñoz, A., Martínez, J. R., \& Stanshenko, E. E. (2007). Study of the chemical composition and biological activity of the essential oils of ten Colombian aromatic plants. Scientia et Technica, $33,165-167$.

Cruz, C. D. (2006). Genes Program: Multivariate Analysis and Simulation. Viçosa, Minas Gerais, Brazil: Ed. UFV.

Dos Santos, F. J. B., Lopes, J. A. D., Cito, A. M. G., De Oliveira, E. H., De Lima, S. G., \& Reis, F. A. M. (2004). Composition and biological activity of essential oils from Lippia origanoides H.B.K. Journal Essential Oil Research, 16, 504-506.

Escobar, P., Leal, S. M., Herrera, L. V., Martínez, J. R., \& Stashenko, E. (2010). Chemical composition and antiprotozoal activities of Colombian Lippia spp essential oils and their major components. Memórias do Instituto Oswaldo Cruz, 105(2), 184-190.

Falk, D. A., Knapp, E. E., \& Guerrant, E. O. (2001). An introduction to restoration genetics. USA: Society for Ecological Restoration and Plant Conservation Alliance.

Ferreira, D. F. (2011). Sisvar: a computer statistical analysis system. Science and Agrotechnology, 35(6), 1039-1042.

Gobbo-Neto, L., \& Lopes, N. P. (2007). Medicinal plants: factors influencing the content of secondary metabolites. Química Nova, 30(2), 374-381.

Henao, J., Muñoz, L. J., Rios, E. V., Padilla, L., \& Giraldo, G. A. (2009). Evaluation of the antimicrobial activity of the extracts of the plant Lippia origanoides H.B.K. cultivated in the department of Quindío. Revista de Investigaciones Universidad del Quindio, 19,159-164.

Instituto Nacional de Meteorología (INMET). (2015). Climatic data. Retrieved from http://www.inmet.gov. br/portal

Köppen, W. (1931). Grundriss der Klima kunde: Outline of climate science. Berlin: Walter de Gruyter.

Martins, F. T., Dos Santos, M. H., Pólo, M., \& Barbosa, L. C. A. (2006). Chemical variation of Hyptis 
suaveolens essential oil under culture conditions. Química Nova, 29(6), 1203-1209.

Meneses, R., Ocazionez, R. E., Martínez, J. R., \& Stashenko, E. E. (2009). Inhibitory effect of essential oils obtained from plants grown in Colombia on yellow fever virus replication in vitro. Annals of Clinical Microbiology and Antimicrobials, 8(8), 1-6.

Morais, L. A. S. (2009). Influence of abiotic factors on the chemical composition of essential oils. Horticultura Brasileira, 27(2), 4050-4063.

Nogueira, M. A., Diaz, G., \& Sakumo, L. (2007). Chemical characterization and biological activity of Lippia alba essential oil grown in Paraná. Revista de Ciências Farmacêuticas Básica e Aplicada, 28(3), 273-278.

Oliveira, D. R., Leitão, G. G., Santos, S. S., Bizzo, H. R., Lopes, D., Alviano, C. S., Alviano, D. S., \& Leitão, S. G. (2006). Ethnopharmacological study of two Lippia species from Oriximiná, Brazil. Journal Ethnopharmacology, 108(1), 103-108.

Oliveira, D. R., Leitão, G. G., Bizzo, H. R., Lopes, D., Alviano, D. S., Alviano, C. S., \& Leitão, S. G. (2007). Chemical and antimicrobial analyses of essential oil of Lippia origanoides H.B.K. Food Chemistry, 101(1), 236-240.

Pascual, M. E., Slowing, K., Carretero, E., Sánchez, M. D., \& Villar, A. (2001). Lippia: traditional uses, chemistry and pharmacology: a review. Journal Ethnopharmacology, 76(3), 201-214.

Ramirez, L. S., Isaza, J. H., Veloza, L. I., Stashenko, E., \& Marin, D. (2009). Actividad antibacteriana de aceites esenciales de Lippia origanoides de diferentes orígenes de Colombia. Ciencia, 17(4), 313-321.

Ribeiro, A. F., Andrade, E. H. A., Salimena, F. R. G., \& Maia, J. G. S. (2014). Circadian and seasonal study of the cinnamate chemotype from Lippia origanoides Kunth. Biochemical Systematics and Ecology, 55, 249-259.

Rojas, J., Morales, A., Pasquale, S., Márquez, A., Rondón, M., Imré, M., \& Veres, K. (2006). Comparative study of the chemical composition of the essential oil of Lippia origanoides collected in two different seasons. Natural Products Communication, 1(3), 205-207.

Sarrazin, S. L., Da Silva, L. A., De Assunção, A. P., Oliveira, R. B., Calao, V. Y., Da Silva, R., ... Mourão, R. H. (2015). Antimicrobial and seasonal evaluation of the carvacrol-chemotype oil from Lippia origanoides Kunth. Molecules, 20(2), 1860-1871.

Silva, N. A., De Oliveira, F. F., Costa, L. C. B., Bizzo, H. R., \& Oliveira, R. A. (2006). Chemical characterization of erva cidreira's essential oil (Lippia alba (Mill.) N. E. Br.) grown in Ilheus, Bahia State,
Brazil. Revista Brasileira de Plantas Medicinais, $8(3), 52-55$.

Stashenko, E. E., Martínez, J. R., Ruíz, C. A., Arias, G., Durán, C., Salgar, W., \& Cala, M. (2010). Lippia origanoides chemotype differentiation based on essential oil GC-MS and principal component analysis. Journal of Separation Science, 33(1), 93-103.

Tangarife-Castaño, V., Correa-Royero, J., Zapata-Londoño, B., Durán, C., Stanshenko, E., \& Mesa-Arango, A. C. (2012). Actividad contra Candida albicans, citotoxicidad e interacción con antifúngicos de aceites esenciales y extractos de plantas medicinales y aromáticas. Revista de la Asociación Colombiana de Infectología, 15(3), 160-167.

Teles, S. (2010). Evaluation of the content and chemical composition of leaves of Lippia alba (mill) n.e.br. and Mentha piperita l. cultivated in Cruz das Almas, Santo Antônio de Jesus e Amargosa, submitted to different harvesting times and drying processes (Master's Thesis). Ciências Agrárias da Universidade Federal do Recôncavo da Bahia, Cruz das Almas, Bahia, Brazil.

Teixeira, M. L., Cardoso, M. G., Figueiredo, A. C. S., Moraes, J. C., Assis, F. A., De Andrade, J., ... Albuquerque, L. R. M. (2014). Essential Oils from Lippia origanoides Kunth. and Mentha spicata L.: Chemical Composition, Insecticidal and Antioxidant Activities. Scientific Research, 5(9), 1181-1190.

Tirillini, B., Velasquez, E. R., \& Pellegrino, R. (1996). Chemical composition and antimicrobial activity of essential oil of Piper angustifolium. Planta Medica, 62(4), 372-373.

Van Den Dool, H., \& Kratz, D. J. (1963). A generalization of the retention index system including liner temperature programmed gas-liquid partition chromatography. Journal of Chromatography, 11, 463-471.

Vega-Vela, N. E., Delgado-Avila, W. A., \& Chacon-Sanchez, M. I. (2013). Genetic structure and essential oil diversity of the aromatic shrub Lippia origanoides Kunth. (Verbenaceae) in two populations from northern Colombia. Agronomía Colombiana, 31(1), $5-17$.

Vicuña, G. C., Stashenko, E. E., \& Fuentes, J. L. (2010). Chemical composition of the Lippia origanoides essential oils and their antigenotoxicity against bleomycin-induced DNA damage. Fitoterapia, 81(5), 343-349.

Zapata, B., Durán, C., Stashenko, E., Correa-Royero, J., \& Betancur-Galvis, L. (2009). Cytotoxic activity of essential oils of Lippia origanoides H.B.K. and major components. Revista Universidad Industrial de Santander, 41(3), 215-222. 